\title{
Forestry Education in China
}

\author{
by
}

Peter J. Murphy ${ }^{1}$ and Ralph W. Roberts ${ }^{2}$

\begin{abstract}
The administration of forestry activities in the People's Republic of China is centrally controlled through the Ministry of Forestry. Forestry education is planned and carried out as an adjunct to the national plan for forestry to meet specific human resource needs. Their educational delivery system is analogous to that in Canada with programs offered at vocational, technical, and bachelors degree levels, and graduate studies for both Masters and Ph.D. degrees at selected universities and colleges. However, recruitment of students, assignment to specialties, and placement of graduates offer interesting contrasts.
\end{abstract}

\section{Résumé}

La gestion des activités forestières de la République populaire de Chine est centralisée sous le Ministère des Forêts. L'éducation forestière est planifiée et appliquée en tant que complément au plan national forestier afin de rencontrer les besoins spécifiques de ressources humaines. Leur système de formation est semblable à ce qui existe au Canada, soit des programmes permettant d'atteindre le niveau professionnel, technique et universitaire, ainsi que la formation post-graduée pour les niveaux de la maîtrise et du doctorat dans certaines universités et collèges. Toutefois, le recrutement des étudiants, le choix des spécialisations, l'embauche des gradués présentent d'intéressants contrastes.

\section{Introduction}

The centrally planned economic system in the People's Republic of China provides an interesting example of human resource development in the forestry sector. Recruitment, education or training, and placement of graduates all form a part of the planning system of the Ministry of Forestry to meet its responsibilities for forest management and production of forest products.

The forests of China comprise only $12 \%$ of the land area (China 1984, 1986). They play an important role in timber supply in this country with its urgent material needs, and are an essential feature in nature conservation, water supply, and erosion control. Since the population is large and the demands on the forests are inexorable, the per capita forest area is only 0.12 ha. As a result, protection and management are primary concerns, and major reforestation and afforestation needs have been identified (China 1986). The national goal is to increase the area of forest cover to $20 \%$ by the end of the century. An expected shortage of qualified forestry practitioners has been identified as an obstacle to achieving this goal. At present the forestry education institutions graduate less than 10000 vocational-technical and professional staff each year, a rate which they estimate will leave them with just $57 \%$ of their targeted staff of 250000

\footnotetext{
Associate Dean, (Forestry), Faculty of Agriculture and Forestry, University of Alberta.

2Director, Forestry Sector, Natural Resources Division, Canadian International

Development Agency.
}

needed by the end of the century. They plan to modernize and expand their schools to reach this educational objective (China 1987).

The National Ministry of Forestry is responsible for the entire forestry sector, including forest management in its broadest sense from the forest resource itself through forest harvesting, wood supply, and operation of the solid wood products forest industries. Its comprehensive responsibilities also comprise nature conservation, forest research, and forestry education. It is for these combined responsibilities that the human resources are required. The focus of this paper is on the forestry education aspect.

\section{National Education System}

The basic concept of the Chinese educational system is generally similar to that in Canada with primary, secondary and post-secondary schooling. However, in the centrallyplanned Chinese system, there are some important differences which must be understood before attempting to draw comparisons.

Although forestry education is primarily a responsibility of the Ministry of Forestry, the system is governed by guidelines of the Chinese State Education Commission which has overall responsibility for the national education system. The main task of the commission is to:

1. develop principles and policies to govern education in China, and to prepare long-term plans, 
2. establish universities and colleges, approve the offering of specialties, and to rule on changes in status of institutions from colleges to universities,

3. determine numbers of students in each institution and to oversee the assignment of graduates to work positions,

4. evaluate institutions,

5. designate "key" universities,

6. operate the thirty-eight national universities under its direct control,

7. direct the provincial Education Commissions,

8. oversee the Education Departments in all other state Ministries, which must report to the State Education Commission, and

9. oversee the provincial education systems.

There are three levels of education in China, levels that also apply to forestry education:

1. Primary - grades 1 to 9 inclusive;

2. Professional and Vocational-Technical - education after grade 9 which may either be in a school such as the Nanjing Forestry School offering a four-year Vocational-Technical Diploma after grade 9, or at a college or university offering a post grade 12 two-year technical diploma, a four-year Bachelor's degree after grade 12 , or graduate studies.

3. Adult Education - education which may be given at elementary, high school, college or university level to upgrade workers, supervisors, technicians and professionals. This category covers cadre 3 training at all levels as well, including programs of the Beijing Institute for Forest Management Cadres.

There are 1054 universities and colleges in China. Of these, $70 \%$ are run by provinces, catering largely to students drawn from within the province or region in which they are located. The remaining $30 \%$ are operated by various national state Ministries to educate students for their particular missions. Students at the Ministry schools are usually drawn on a China-wide or regional basis to serve national needs.

\section{Forestry Education}

There are ten educational institutions attached to the Ministry of Forestry, administered by its Department of Education from Beijing. These comprise six forestry universities and colleges, three forestry schools, and one institute for cadres, as listed below. The relationship of the universities and colleges to the Ministry of Forestry and the State Education Commission is illustrated in Figure 1.

1. Beijing Forestry University

2. Northeast Forestry University

3. Nanjing Forestry University

4. Northwestern College of Forestry

5. Southcentral College of Forestry

6. Southwestern College of Forestry

7. Nanjing Forestry School

8. Ningbo Forestry School

9. Baicheng Forestry School

10. Beijing Institute for Forest Management Cadres

${ }^{3}$ Cadre is the term used in China to describe management and supervisory staff At the senior levels cadres are roughly analogous to our deputy ministers, chief foresters, chief executive officers and directors. At junior levels they correspond to foremen and supervisors.

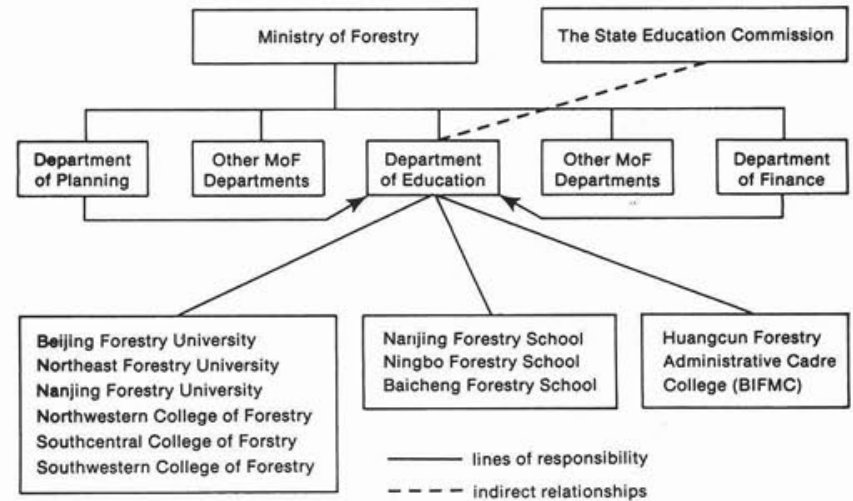

Figure 1. Forestry education institutions operated by the Ministry of Forestry,

In addition, there are five forestry colleges attached to provincial governments. Two of these, Jilin Forestry College and Zhejiang Forestry College, are administered through their respective provincial government forestry departments in view of the importance of forestry to those provinces. The other three, Inner Mongolia, Fujian, and Hebei Forestry Colleges are administered by their respective provincial Education Commissions. The Ministry of Forestry plays an advisory role with respect to curricula, specialties and enrollment, and tries to develop strong working relationships with them.

It is important to recognize that the forestry universities, colleges and schools are planned and operated primarily to meet human resources needs within the Ministry of Forestry and related forestry sector agencies. They form a part of the broader Ministry organization to plan and administer China's forest resources and forest enterprises.

Formalizing of the forestry education system started in 1952 within the Ministry of Forestry (then part of Agriculture) with establishment of the higher-education institutions at Beijing, Nanjing and Harbin (Northeast). Subsequent consolidations and identification of other schools has gradually led to the present network.

\section{Forestry Programs}

The forestry universities and colleges offer four-year bachelor degrees in forestry. A bachelor degree in forestry is also available through 18 forestry departments in agricultural colleges in provinces where there is no full forestry school. Some of these colleges are attached to the Ministry of Agriculture, others to provincial Education Commissions. All 29 of these universities and colleges offer bachelor degrees in forestry approved by the Ministry of Forestry. The Masters degree is available in 18 specialties at 20 of these, and the Ph.D in 12 specialties at the three key Forestry Universities. The responsibilities of academic staff at colleges and universities include both teaching and research.

There are 42 forestry schools that offer vocationaltechnical education, of which only three are run by the Ministry of Forestry. These include the Nanjing Forestry School, Ningbo Forestry School near Shanghai, and the Baicheng Forestry School in Jilin Province. These are operated as model schools to set standards and to afford the Ministry an opportunity to offer some of the specialties not required from all schools. Of the remaining 39 forestry schools, 27 are 
attached to the provincial forestry departments, and 12 are attached to district forestry bureaus within provincial forestry departments. The relationship among these and provincial governments is shown in Figure 2.

Education at the elementary level is usually operated by local governments. However, in forested areas, especially the northeast, this level of education may also be supported by the Ministry of Forestry as part of its broader forest management mandate. For example, 800000 students in China living in forested areas attend elementary and secondary schools fully supported by the Ministry of Forestry, since local authorities are unable to provide the level of educational support necessary. As a result, the Ministry of Forestry also has a teacher-training department in the Northeast Forestry University to provide teachers to instruct in the elementary and high schools for which they are responsible. At present, 600 of the 3000 students at the Northeast Forestry University are teachers, and plans are to set up a Teacher's College within the University. Other Ministry of Forestry institutions also offer teacher training.

Specialization is a notable feature of the educational programs, and is developed to a remarkable extent. Among all the forestry universities, over 30 specialties are offered. A composite list of the majority of these is shown in Table 1. These represent a higher degree of specialization than at our Canadian institutions, but apparently suitable in China where education for the broader forestry sector is provided, and where specific needs in the work place are identified, with enrolment structured accordingly as part of the five-year planning process. The universities and colleges all offer the general forestry specialty, but not all other specialties are offered at all institutions.

Each specialty is based on a separate program of studies. Those within any one department may have many courses in common, but the distinction between them may begin as early as the first year of studies. In selecting Chinese applicants for graduate studies in Canada, it would be important to carefully review the transcript to determine the specific courses taken in the particular specialty indicated. Among the various universities and colleges the programs for any one specialty are virtually the same, except for some local emphasis. The offering of them is approved by the Department of Education of the Ministry of Forestry. A typical list of subjects for the forestry specialty is shown in Table 2. A foreign language is required within all degree specialties. English is most commonly taken now, with other choices usually among German, Russian, Japanese and French. Language training facilities within the schools help to enable students to utilize

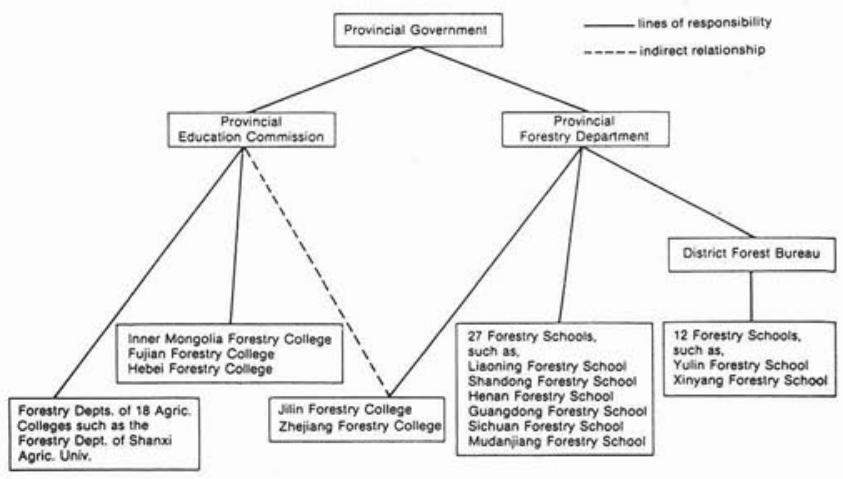

Figure 2. Provincial forestry education institutions.
Table 1. Composite list of the major specialties offered in the bachelor degree programs at forestry universities and colleges
Forestry

Forest protection

Landscape architecture

Forest ecology

Soil and water conservation

Sand control

Forest resource inventory and planning

Wildlife management

Nature reserve management

Resource management in protected areas

Economic forestry species

Wild plant resources

Logging engineering

Wood science and engineering

Forest products chemistry and engineering

Wood based panels

Wood processing

Furniture design and

manufacturing

Pulp and paper of production

Motor vehicle engineering

Felling and transportation engineering

Cadre training

Forest roads and bridge engineering

Civil engineering

Forest economics

Finance and accounting

Forest administration

Planning and statistics

Wood trade

Biology

Mathematics

Physics

Chemistry

English

Political education

Forest policy

Physical education

Forest machinery
Electrification and automation

foreign journals and references, and help to prepare potential graduate students for study abroad.

The university school year is about 10 months in length, providing for two four-week breaks in winter and summer. Students generally use this time for vacation. The students do not typically work during the breaks since they receive state support and scholarships. A 20-week practicum and thesis during the final year are required for graduation.

Offering of advanced degrees is a relatively recent innovation. From 1949 to 1982, under the egalitarian philosophy of Chairman Mao, no formal advanced degrees were offered. Although individuals undertook studies, these did not lead to advanced degrees. An amendment to the education legislation in 1982 enabled the State Education Commission to authorize granting of degrees at the Masters and Ph.D. levels. These each require three years of graduate study after the previous degree. Since this is a recent change, relatively few of the teaching staff have advanced degrees. Those with graduate degrees are distributed bimodally among older pre-liberation staff who studied abroad, and younger staff who have either studied abroad or in China.

Two-year technical education is offered through the universities and colleges as an adjunct to their predominating degree programs. Student numbers at this level are relatively few. Most non-degree training takes place at the vocationaltechnical level within the 42 forestry schools. These schools offer a four-year program after a grade 9 level of secondary schooling. Typical subjects in the forestry specialty at this level are listed in Table 3. As in the degree programs, many specialties are offered, the availability of which usually reflects regional needs.

A second option for obtaining advanced education is available through correspondence courses. A university-level program has been recently initiated that will take a student five years to complete the bachelor's degree requirements. Candidates must first pass the national university entrance examination described later, and be selected. Although most 
Table 2. Typical bachelor's degree program in the general forestry specialty

\begin{tabular}{lr}
\hline Subjects & Hours \\
\hline History of C.C.P. & 80 \\
Philosophy & 80 \\
Political economy & 80 \\
Physical education & 120 \\
Foreign language & 240 \\
Higher mathematics & 140 \\
General physics & 110 \\
Inorganic chemistry & 90 \\
Analytical chemistry & 80 \\
Organic chemistry & 100 \\
General botany & 120 \\
Dendrology & 80 \\
Meteorology & 70 \\
Surveying & 80 \\
Soil science & 120 \\
Plant physiology & 100 \\
Genetics & 60 \\
Statistics & 100 \\
Forest ecology & 60 \\
Forest mensuration & 80 \\
Forest entomology & 60 \\
Forest pathology & 50 \\
Tree breeding & 40 \\
Silviculture & 60 \\
Forest management & 60 \\
Forest utilization & 80 \\
Forest economics and policy & 70 \\
Extra classes & 10 \\
Total & 500 \\
\hline & \\
\hline
\end{tabular}

of the instruction is by correspondence, some annual residence time at a university is also required. For candidates with a two-year technician-level diploma after grade 12, the correspondence program requires three years including residence time.

Correspondence courses are also available to forest workers to enable them to upgrade to a vocational-technical level. This involves a combination of correspondence, 1.5 months per year at school, and work experience. Entry requires the same minimum of nine years basic schooling and passing of the provincial school entrance examination. The vocational-technical correspondence program requires at least four years to complete.

Training of cadres or senior leaders and administrators for the forestry sector is another major education responsibility of the Ministry of Forestry. A new senior cadre training centre, the Beijing Institute for Forest Management Cadres (BIFMC), is being constructed south of Beijing at Huangcun. This is designed to replace the former cadre training school established in 1983. The objective of this institute is to train senior leaders within the Ministry of Forestry from the level of Director of County Bureaus and higher. Since the college is still under development, the forestry universities and colleges are also training senior cadres. However, after the Huangcun institute is operational it will become the major centre for senior administrators. The universities will then offer cadre training primarily to professional and technical people, focusing on trainees in their respective fields of strength wood products at Nanjing, forestry at Beijing, and forestry, engineering and forestry machinery at Northeast. The senior cadre training is currently planned as a two-year residential course but may evolve to a separate four-year degree. Their focus and intent is roughly analogous to the Bachelor of Commerce and MBA programs in Canada.
Training of cadres at vocational and junior levels is developed at and coordinated by the Nanjing Forestry School, which offers both residential and correspondence course work.

\section{Administration and Finance}

Financing of the universities and colleges comes from two major sources. Capital construction and equipment items over $50000 \mathrm{RMB}^{4}$ (Yuan) are provided to the Ministry of Forestry through the State Planning Commission. The Ministry of Finance provides funds to cover operating costs including salaries, maintenance, equipment less than $50000 \mathrm{RMB}$, and student scholarships. Funding is provided on a formula based on the numbers of students and staff. The grants component based on student enrollment in 1987 was 2000 RMB per student year.

In the forestry programs virtually all students receive scholarships from the Ministry of Forestry. There is no tuition fee and the room and board charges are minimai. The provision of scholarships is designed to try to encourage more candidates to select forestry as a field in which to work. In other disciplines, apparently only small percentages of students receive scholarships.

Funding is provided on the basis of five-year plans, so at the beginning of a planning period, funding levels are assured and known in advance. For example, the new cadre training school (BIFMC) at Huangcun is being developed on the basis of the planned and projected funding.

Several centres have been designated as "key" institutions. These are usually those judged to be the best, those to be developed as models, or ones selected to test new programs or systems. The three forestry universities have been identified by the Ministry of Forestry as "key" universities - Beijing, Nanjing and Northeast. In addition, Beijing Forestry University has been identified by the State Education Commission as one of the national "key" institutions. The designation provides additional funding to those particular institutions. The designation also enables a lower staff:student ratio to try to ensure a higher quality of education. The current official staff:student ratios are 1:6.5 as an overall average, $1: 6.4$ at "key" universities, and 1:6.6 at the others. The designated staff include professors, associate professors, lecturers, and teaching and research assistants. However, unofficially, the actual working ratios appear to suggest greater staff numbers, although some are directed more to research activity.

The staff:student ratios are more favourable than those at Canadian institutions. Direct comparison is difficult since circumstances are not the same. The lower ratios in China are affected by several factors. Staff members include the positions of assistants in laboratories, research and teaching who perform functions that would be done in Canada by nonacademic staff. Some of the student numbers cited did not include correspondence or short-course students for whom some of the teaching staff would be responsible. Some of the teaching staff hold positions largely involved with research and so may have little contact with students. Finally, the ratio probably reflects the general employment philosophy intended to make work available to as many qualified people as possible.

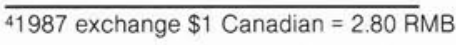


Table 3. List of typical subjects in the Forestry specialty of the four-year vocational-technical school programs

\begin{tabular}{ll}
\hline Politics & Botany \\
Mathematics & Forestry ecology \\
Foreign language & Mathematical statistics \\
Chemistry & Forest mensuration \\
Physics & Electronic computing \\
Physical education & Forest tree breeding \\
Chinese & Silviculture \\
Botany & Forest management \\
Dendrology & Forest disease and pest control \\
Soil science & Forest regulation \\
Meteorology & Forest economics and \\
Plant Physiology & management \\
& Landscape plant culture \\
\hline
\end{tabular}

The universities, colleges and schools are all selfcontained individually-sited institutions so the forestry institution must offer all the courses required in a program from their own resources. The teaching staff therefore includes teachers of such basic academic subjects as mathematics, chemistry, physics, biology, languages, physical education and others. Administratively, the institutes are also responsible for all services and ancillary needs including day care and both primary and secondary schooling for children of staff.

\section{Student Selection and Placement}

Selection of students to attend universities and colleges is based on a national entrance examination and an evaluation process. The State Education Commission offers a national entrance examination every year. It comprises tests in two general subject areas - social sciences, and science and technology. Altogether it consists of six to seven tests taken over a three-day period, usually during the second week of July. The Education Commission is responsible for the examinations which are all given on the same days and at the same times throughout China. Supervision of the examinations is conducted by local education authorities.

Students in their high school graduation year, or previous high school graduates, may apply to write the examinations, usually at their home locations. Forestry graduates of vocational-technical programs are also eligible to apply for university admission after two years of forestry experience. Part of the application process comprises completing a form that asks applicants to list their preferences for universities and programs. Applicants are given the opportunity to list preferences for three "key" universities, and for three other universities. For each institution listed they are also required to state the degree program and specialty of preference. The form includes a final choice question which asks, in essence: if not selected by any of the six institutions of choice, would the applicant accept placement at some other institution or in some other program or specialty? If the applicant replies "Yes", as virtually all applicants do, it provides an opportunity to be placed somewhere else or in any other program, rather than missing out on an opportunity to attend one of the limited and valued places for higher education.

This latter option is important to the individual, since admission to an institution of higher learning virtually ensures a substantially more rewarding career opportunity. Of 2.5 million high school graduates, plus potential applicants from among the 1.0 million from vocational-technical high schools, only 650000 can enter university or college.
Information on career choices is made available in newspapers and at schools. In the case of forestry and agriculture, as mentioned previously, the availability of scholarships is intended as an inducement to enter these fields which are commonly perceived to be practised in the "country", away from urban amenities. The number of places in each specialty in forestry is set by the Ministry of Forestry with reference to its five-year plan which details human resource needs by specialty, and which has been approved by the State Planning Commission. The same procedure applies to selection of students for graduate studies. University and college enrollment is scheduled to comprise $10 \%$ graduate students by 1990 .

Selection of actual students to fill the available places is a major and complex undertaking, beginning during the first week of August after the examination results have been compiled. The "key" universities have first choice of applicants. However, the "key" universities are expected to serve the national interest, so are required to select students nation-wide on the basis of a quota from each of the provinces. This is done in expectation that the applicants would return to their own areas upon graduation to ensure a dispersal of the most qualified to all regions.

For example, Beijing Forestry University, as a "key" institution will have first choice of applicants. However, for example, it may be able to select only two applicants from the Beijing area to enter the forest management specialty. The University would review the applications at the National Registry looking for those who listed the Beijing Forestry University and the forest management specialty as their first choices. Initial identification of possible candidates is made on the basis of grades. However, actual selection is based on an evaluation from among the candidates in the upper group based on presumed interest and probability of willingness to work in forested areas - using such criteria as whether or not the applicant was raised in the countryside, physical condition, or raised in a "forestry" family. In filling specialties for which no applicants had applied, selection could be first considered from among those with other forestry interests, then among those with "forestry-related" preferences, and finally even from among those who made no reference to forestry whatsoever in their applications.

If an applicant had a particularly high mark in the national examinations that individual could be first selected by any one of the other national "key" universities, regardless of whether or not it offered forestry, and, even though forestry may have been the applicant's stated preference. As a result of this system, no one university or program is able to determine how many students applied to attend there, since all applications are handled by the Central Registry and all represent a variety of choices.

The selection process continues through the non-key universities and colleges with applicants selected on a regional or provincial basis. With approximately three million applicants from whom to choose, only about $20 \%$ can be accepted so there are more than enough from whom to select. Those unsuccessful may reapply the following year.

The forestry universities and colleges also offer a twoyear technician program based on a grade 12 education. Students for these are also drawn from among those who had applied for university entrance but who had not been selected by any of the universities or colleges. 
Selection of students to attend the forestry schools at vocational-technical level is also based on examinations, but ones set at the provincial level. Candidates need to have completed grade 9 in order to be eligible. Applicants are usually restricted to those residing in the province or region served by the particular school. However, those schools operated by the Ministry of Forestry can and do select from all over China on the basis of assigned quotas. Students in forestry are often selected from specific communities to which those individuals would be assigned after graduation in expectation they would be content to stay there to work.

The failure or dropout rates in higher education institutions are understandably very low, estimated variously at about 2 to $5 \%$ over the entire four-year degree program. Students are among the top-ranked academically, and they recognize both the opportunities of advanced education and the consequences of not succeeding.

In line with the central planning philosophy, graduates are assigned to their positions after graduation based on their specialties, home area locations, and tempered by particular attributes demonstrated at school. At the forestry universities and colleges under control of the Ministry of Forestry, $30 \%$ of the graduates are assigned to their first jobs by the Ministry, and the remaining $70 \%$ assigned by the university. The Ministry first places its $30 \%$, with graduates dispersed all over China according to the national plan. Individuals may also be assigned to other Ministries with need for foresters, such as the Railway Ministry, upon request from them. The university assigns its share of students in consultation with the provinces, either nationally or regionally, and sends the required number according to specialty. Once students are assigned to a province, the university is no longer involved in subsequent placement, and tends to lose contact with them. The graduates may thus be assigned by the province to any one of a variety of positions within the provincial or county forestry units, forest enterprises, research units, or schools at provincial discretion. Placement, officially, is made irrespective of sex. Graduates of provincial schools are assigned by the provincial forestry bureaus except for a few identified specialties for which the Ministry of Forestry does the placement.

Although placement of graduates is implicit in the system, the system is apparently not as arbitrary or firm as suggested. Graduates are invited to complete a form stating their preferences for employment, requests that are met to the extent possible. In any event, graduates are also asked to honour the needs of the state, and to serve wherever needed. However, there apparently remains some difficulty in posting graduates to locations in which working conditions are perceived to be difficult, in which cases graduates have evidently shown some success in avoiding those specific assignments.

\section{Summary}

Virtually all forestry employment in China is with the Ministry of Forestry within its wide-ranging operations, both geographically and by discipline. In the centrally-controlled approach to planning, human resource needs are identified through five-year projections, and the education system is designed to provide for those projected needs. The forestry education system in China includes the university technicalvocational oriented training programs analogous to our system, as well as the in-service training functions provided here by government agencies and industry. The combination of selection of students from among the academically toprated and the dedicated teaching has resulted in placement of some excellent people in the forestry sector

\section{Acknowledgments}

Most of the information for this paper was derived during extensive discussions with Mr. Zhang Guanli, Director of the Forestry Education Division of the Ministry of Forestry, PRC. His interest, obvious dedication and utmost of patience are much appreciated. The interviews and visits took place during a forestry education mission to the People's Republic of China in 1987 supported by the Canadian International Development Agency. The background material was compiled as part of the mission report to CIDA, and is utilized here with their kind permission.

\section{References}

1. China. 1984. A brief account of China's forestry. Ministry of Forestry, Beijing. 20 p.

2. China. 1986. Statistics of China's forestry. Ministry of Forestry, Beijing. 30 p.

3. China. 1987. Proposal for cooperative forestry education development project between the Chinese Forestry Ministry and the Canadian International Development Agency by the Ministry of Forestry, PRC. Official request to Canadian International Development Agency. 5 p.

4. Ministry of Forestry. 1987. Organization charts of the Ministry of Forestry and the forestry education institutions. Ministry of Forestry, Beijing. 2 p.

5. Roberts, R.W., P.J. Murphy, R. Coleman, W. MacDonald and P. Bellefleur. 1988. Forestry education mission to China - final report of the CIDA mission. CIDA. $311 \mathrm{p}$.

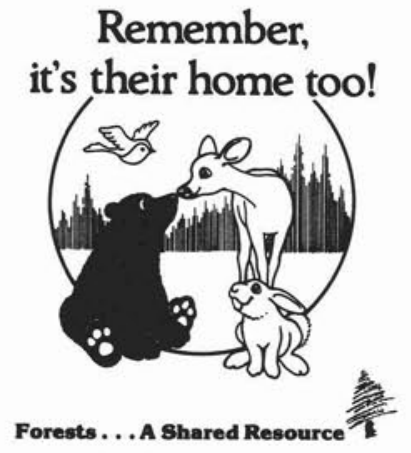

EDWARD

S. FELLOWS

\author{
Canadian Institute of Forestry \\ Forest Products Research Society \\ etc.
}

\title{
FORESTRY \& FOREST PRODUCTS CONSULTANT
}

Mail address:

P.O. Box 354 ,

FREDERICTON, N.B

E3B $4 Z 9$
Office location:

404 Queen Street,

FREDERICTON, N.B.

Phone: (506) 455-3232

INDUSTRY DEVELOPMENT - FOREST PRODUCTS -

FOREST ECONOMICS, POLICY AND ADMINISTRATION 